Book review

(C) Journal of International Students

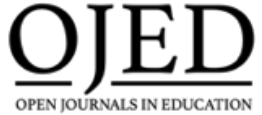

Volume 11, Issue 4 (2021), pp. 1006-1009

ISSN: 2162-3104 (Print), 2166-3750 (Online)

doi: $10.32674 /$ jis.v11i4.4019

ojed.org/jis

\title{
Education Abroad: Bridging Scholarship and Practice
}

Edited by Anthony C. Ogden, Bernhard Streitwieser, and Christof Van Mol, 2021. Routledge.

ISBN 978-1-138-36427-1 (hbk).

ISBN 978-1-138-36428-8 (pbk).

ISBN 978-0-429-43146-3 (ebk)

Reviewed by Hau Trung Ho, Thu Dau Mot University, Vietnam

Prior to the disruptions caused by COVID-19, 5 million students had left their home countries to study overseas in 2019, and it was predicted that 8 million students would be studying abroad by 2025 (ICEF Monitor, 2015; Institute of International Education [IIE], 2019). In the wake of the pandemic, international students remain important to many countries around the globe (IIE, 2019). Education Abroad: Bridging Scholarship and Practice is a timely book that deals with enduring issues in international education. The contribution of the book and its editors, Anthony $\mathrm{C}$. Ogden, Bernhard Streitwieser, and Christof Van Mol, to changing thinking about international education was recognized by the 2020 Association for the Study of Higher Education (ASHE) Council for International Higher Education award. This award is given for significant state-of-the-art research.

In their introduction, the editors locate the volume within the broad context of international education and as a critical review of current issues in education abroad research. The contributing authors include leading scholars such as Rachel Brooks (United Kingdom) and Betty Leask (Australia), plus many others in the field. The book is well structured into five parts (Participation, Programming, Student Outcomes, Institutional Outcomes, and Societal Outcomes), with 14 chapters plus an introduction and a conclusion. Each chapter is introduced by highlighting key points that effectively guide the reader. The suggestions for further reading at the end of each chapter are especially useful in locating resources and gaining in-depth understanding of the topics of interest. 
Part 1, Participation, consists of two chapters examining factors that affect participation in education abroad. In the first, Brooks and Waters consider students' decision-making process at the micro-, meso-, and macro-levels of study abroad, and recognize the critical role that "widening access to education abroad opportunities" play in practice. They argue for governments and institutions to take responsibility and measures to enhance access. In Chapter 2, Netz and colleagues focus on the factors that affect students' access to study abroad and that potentially result in inequalities in participation.

In the second part, Programming (two chapters), the authors analyze the relationships between various education abroad programs and their components (e.g., program design, modes of instruction, and accommodation), which contribute to outcomes and therefore to improving programs. In Chapter 3, Moore, Menlove, and Pisano consider the importance and educational values of various program types. Identifying implications for practice, these authors emphasize the importance of "a well-designed program" and "holistic programming" that "incorporates the host community and considers impact on local stakeholders" (p. 51). In the following chapter, Gozik and Oguro focus on program components (e.g., modes of instruction and support services) and how they may impact student outcomes.

The crucial topic of Student Outcomes is dealt with in Part 3 (five chapters), where the authors focus on rich and diverse issues, namely students' academic development, language improvement, sense of place constructed by identity and life history, identity as global citizens, and employability. Chapters 5 and 6 respectively foreground the roles academic development and language proficiency play for education abroad and student outcomes, and discuss institutional interventions to support positive outcomes for students. Place and identity are of growing interest in international education and Glass and Holton in Chapter 7 recognize the role that education abroad leaders play in helping students develop their sense of place. In a different and novel tack, Doerr, Puente, and Kamiyoshi (Chapter 8) argue for expansion of the scope of international education to include the identities of other mobile populations (e.g., immigrants) who take part in international education (e.g., through modifying programs to enrich immigrant students' existing intercultural competence). Student employability is the outcome examined by Wiers-Jenssen, Tillman, and Matherly who draw attention to the disconnect between education abroad programs and the development of skills important to students' employability.

Shifting from student outcomes to those of Institutional Outcomes, the three chapters of Part 4 examine questions around institutional impact, curriculum integration, and faculty engagement in education abroad. Haupt and CastielloGutiérrez (Chapter 10) examine the relationship between students' education abroad and their success in terms of retention rates and persistence to graduation, and between education abroad programming and institutional ranking. Financial benefits to institutions are also discussed in relation to alumni donations. In Chapter 11, Leask and Green focus on the internationalization of the undergraduate curriculum and challenge the notion of curriculum integration (i.e., combining major-specific abroad programming and undergraduate degree plans) 
that is often adopted in the United States. Leask, Whitsed, de Wit, and Beelen (Chapter 12) critically examine ways to encourage engagement of faculty in internationalization. They argue for multifaceted engagement to be an integral part of an institutional internationalization strategy.

Societal Outcomes represents an often-neglected dimension of education abroad but is fittingly given due attention in the final part of the book (two chapters), with the contributions recognizing that the goal of education abroad is to create a positive impact on society. That actual societal impacts are not always desirable is recognized by Van Gaalen, Huisman, and Sidhu (Chapter 13) who examine national policies on education abroad outcomes, focusing on consequences (e.g., negative impact on environmental sustainability and economic inequality). Ziguras and Lucas (Chapter 14) look at how education abroad may impact host communities (e.g., in terms of cultural and political effects), and suggest that three principles - positionality, reciprocity, and intentionality - be used as practical measures to help educators understand the impacts of host communities and local partners. In concluding the book, the editors suggest seven areas to be further researched drawing on previous chapters (e.g., issues related to selectivity processes and social stratification, and mechanisms of education abroad decisions).

Education Abroad: Bridging Scholarship and Practice provides a broad picture of the current field of education abroad for practitioners and emerging and experienced researchers. As an early career researcher in the field of international education, I found this book comprehensive and useful. The authors achieved their aim in retaining "the simplicity and accessibility necessary for active utilization by practitioners and emerging scholars" (p. xxiii). The book extended my understanding and thinking about education abroad. The suggestions for further research have helped me identify directions for my future research.

This book was developed prior to COVID-19. Although international student numbers in major host countries have been severely impacted by the pandemic, study abroad will continue to be desirable for many. As such, the insights into international education offered by this book remain valuable.

\section{REFERENCES}

ICEF Monitor. (2015). Four trends that are shaping the future of global student mobility. https://monitor.icef.com

Institute of International Education. (2019). A quick look at global mobility trends. https://www.iie.org/en/Research-and-Insights/Project-Atlas/ExploreData/Infographics/2019-Project-Atlas-Infographics 
Hau Trung Ho earned his PhD from Victoria University of Wellington, New Zealand. He was the recipient of the Postgraduate Research Excellence Award 2020. His research interests are in higher education, international education, and international students' experiences. He can be reached via email at hauht@tdmu.edu.vn. 